\title{
A Research on Marxist Foothold of Ideological and Political Education in China at Present
}

\author{
Jing Wang \\ Department of Moral Education, Zhongzhou University, Zhengzhou, 450044, China
}

\begin{abstract}
Keywords: Ideological and political education. Marxist theory. Foothold. Theory of human nature. Marxist philosophy
\end{abstract}

\begin{abstract}
Marxist philosophy summarizes that people have both social attribute and natural attribute. Marxism deems that people have natural character and cannot be separated from the society or survive alone. Being similar to things, people also develop and change. When people remold the objective world, they also drive social development. At the same time, social development reacts upon people. Thus, human being and the society cannot be separated from each other but have close relationship. In discussion about human nature, Marxism summarizes objective laws of social development of human beings, which acts as a starting point and foothold of ideological and political education simultaneously. This thesis will combine with theories of Marxism, which are related to human beings, to discuss Marxist foothold of ideological and political education in China at present.
\end{abstract}

\section{Introduction}

Ideological and political education is a practical activity. Being different from other practical activities, objects of practice of ideological and political education are people. Since people have difference in mentality and thinking, ideological and political education is a complicated practical activity. To improve achievements of ideological and political education, it is essential to learn human nature comprehensively and profoundly. Marxism's discussion and annotation about human nature are very scientific. The theory of human nature in Marxism is scientific world outlook and methodology. On the basis that the theory of human nature in Marxism has been comprehended sufficiently, ideological and political education can be developed better. The following content will use the theory of human nature in Marxism as a foothold to analyze researches on ideological and political education in China at present.

\section{Necessity of implementation of ideological and political education}

Development of integration of world economy enables cultures of all countries in the world to be communicated, integrated and permeated sufficiently. Similarly, with Reform and Opening-up, many foreign cultures enter China, which makes Chinese culture show d trend of diversified development. Thus, continuous enhancement of Chinese people's ideological and political education can not only make our excellent traditional thoughts be inherited and developed but also drive social consciousness of China to develop healthily and actively. On the premise that healthy and positive social consciousness is kept, China can cope with impacts of bad ideology and culture on our country. In the Report of the 17th National Congress of CPC, the Party points out it is essential to combine with current national conditions with scientific world outlook and methodology of Marxism to carry out ideological and political education for Chinese people and advocate national spirit of China continuously.

Marxism is abstract and profound theory. Thus, it is necessary to convey these theories to Chinese people in a straightaway way to make people accept and master them more easily. After Marxism has experienced such long-term development, practice shows that it is scientific development view and methodology. Therefore, it is of broad and profound significance to spread world outlook and methodology to Chinese people. 
China is a developing socialist country, so socialist ideology is major ideology of our country. However, with further development of economic globalization, capitalist culture gradually permeates our country and has some influence on our social consciousness as well as ideology and culture. Thus, it is essential for China to enhance ideological and political education.

\section{Marxist foothold of ideological and political education}

Marxism is scientific world outlook and methodology. Marxist philosophy proposes that human beings have social attribute. Social being determines social consciousness. In another word, material decides consciousness. Being the same as animals, people also derive from nature and are results of long-term development of nature. The most obvious difference between human beings and animals is that the former has social attribute. People exist in the society and transform human society via remolding objective world. In the process in which people remold the society, their relationship with the society becomes closer and closer. When people satisfy their own demands, the objective world also changes. People's social attribute is more and more prominent in this practice and then develop continuously. In Marxist materialism, human being is a community of nature and society. People's social nature makes the society change constantly, i.e., in the process in which people remold the world continuously, productivity develops endlessly, production and mode of distribution change and system of ownership of the means of production varies. All of these result in the situation that social being (material) changes constantly and social material decides social consciousness. For instance, the phenomena that productivity was backward in feudal society and means of production were owned by landowners formed ideology of feudal society. Similarly, social productivity of capitalist society and means of production are owned by individuals, which result in capitalist ideology. Ideological and political education is established based on human being. Via carrying ideological and political education for people, level of people's thoughts can be improved continuously. According to Marxist materialism philosophy, social consciousness reacts upon social material. Thus, it is known that favorable ideology of Chinese people can drive development of social economy in China. On the contrary, development of our productivity will be hindered seriously. Thus, it is quite essential to develop ideological and political education in China based on Marxism. Improvement in people's thoughts and ideology can make social culture and productivity of China obtain long-term development, which is of profound significance for revitalization of Chinese nation.

\section{Principles of our ideological and political education based on Marxism}

\section{Marxist materialism philosophy guides ideological and political education of China}

Marxist philosophy is an important component of Marxist theory. The fact that Marxist philosophy is scientific world outlook and methodology is reflected by the situation that it treats and remolds the world materialistically and dialectically. In detail, theory of practice is one of the cores of Marxist philosophy. Thus, final objective of Marxist theory is practice. Hence, ideological and political education of China must approach reality as much as possible. Since Marxist theory is complicated and profound, the number of people who can learn Marxism profoundly is small. Consequently, it is necessary simplify profound theoretical knowledge, make it press close to people's life and level of knowledge structure and develop ideological and political education at school gradually. At the same time, China is a country with glorious history and bright culture. When China develops ideological and political education, it should combine with our excellent traditional culture and our national features to do so. Educational culture develops constantly nowadays, which makes people's sense of independence be enhanced gradually. Thus, ideological and political education must not rigidly adhere to forms but adopt flexible methods to drive people to accept and learn content of ideological education.

\section{Ideological and political education should combine with national conditions}

Marxism is materialistic dialectics, which emphasizes we should treat the world from a developing perspective. Consequently, ideological and political education of China should be improved 
continuously with social development. Meanwhile, keep pace with the times and carry out innovation for content and methods of ideological and political education. Besides, combine Marxism with practical situations of China, convert Marxism into the one with sinicization, make Marxism serve ideological and political education of China and deepen course of our ideological and political education continuously.

\section{Exert people's subjectivity in ideological and political education sufficiently}

Marxism is cognition of human being ultimately no matter how its philosophy of social history and materialistic dialectics guide people to remold and treat the world and carry out practice. Thus, people are subjects in ideological and political education. Currently, ideological and political education of China should exert people's positions as subjects in ideological and political education and develop ideological and political study for people with guidance and instructions of ideological and political educators. Ideological and political education can be really put into practice only when people's independent learning has been excavated. Dominance of ideological and political education refers to educational content cannot be imparted to people compulsively when ideological and political education is implemented but various methods should be used to guide people to accept ideological and political education autonomously.

\section{Gradualness of ideological and political education}

Marxism is a system, which is composed of three aspects, i.e., Marxist philosophy, Marxist political economics and scientific socialism. The three aspects have correlation and interinfiltration, so the relationship among them cannot be separated artificially when ideological and political education is carried out. Instead, Marxism should be regarded as a system to develop ideological and political education step by step. This can not only makes people master connotation of Marxism macroscopically but also enable them to start with a microcosmic view and use Marxism to guide people's practice.

\section{Ways to enhance ideological and political education in China}

Ways to develop ideological and political education under guidance of the theory of practice

Marxist philosophy offers theoretical guidance and feasible methods to people to recognize and remold the world, which provides theoretical guidance for ideological and political education in China at present. On the one hand, ideological and political education in China should not only study ways to development ideological and political education in China and sinicization of Marxism but also use theories to guide practice and combine with practical situations, educational content and methods to develop ideological and political education. On the other hand, ideological and political educators should accumulate teaching experience in practical work and summarize causes for success and failure to offer effective help to ideological and political researches. Utilize theories to guide practice and adopt practice to verify theories. Only in doing so can the objective that ideological and political education will be better and better be realized.

Currently, ideological and political education in China pays excessive attention to theoretical researches but ignores practical teaching. This is not correct. As framework supporting practice, ideological and political education theory makes research achievements of Marxist theory affect ideology of all countries in the world constantly. At the same time, enlarge practical activities of ideological and political education to maximize achievements of ideological and political education in China and withstand infringement that is caused by bad cultural consciousness and ideology for Chinese people. Ideological and political education work of China should consult successful experience of ideological and political education in other countries sufficiently, absorb research achievements and educational methods of ideological and political education in foreign countries, combine with national conditions of China, and bring forth new ideas to methods and theories that are appropriate for ideological and political education in China.

Ideological and political education in should approach Chinese people as much as possible

Cultural economy of China has developed rapidly since Reform and Opening-up, especially in recent years, which improves cultural quality of Chinese citizens to some extent and drives Chinese 
people to awaken their self-awareness. Since Chinese people have different educational background, life experience, cognitive level and value, these differences in people's mentality and intelligence bring difficulty to ideological and political education in China. Thus, in order to make ideological and political education benefit all Chinese people, it is essential to popularize, simplify and visualize abstract, complicated and profound Marxism to make all Chinese citizens master connotation behind Marxism. Thus, we need expand content of Marxism and add national features of China and era characteristics in order to popularize the ideological and political education whose main content is Marxism.

Features of ideological and political education decide that its implementation should be based on current era features and ideology as well as look forward to the future. Ideological and political education is featured by foresight and foreseeability. Meanwhile, it should accord with current national conditions. Thus, Chinese ideological and political education based on Marxism must be appropriate for Chinese people from different stratums, analyze specific problems according to specific conditions and use different methods and education content for citizens with different degrees in order that ideological and political education of China can have pertinence and be appropriate for the masses as well. At the same time, ideological and political educators should establish correct opinions because ideological and political education is a long process. Since ideological and political education is an imperceptible process and people change their thoughts and opinions in education gradually, we must not be anxious for success or accomplish it in an action when we carry out ideological and political education. In fact, we should develop various kinds of activities that approach people's life to make them learn and practice content of ideological and political education when they participate in activities.

\section{Develop Marxism with Chinese characteristics and enhance ideological and political education}

This thesis has mentioned that Marxism is abstract many times. Its abstraction refers to Marxist theory applies politicized language which has been highly summarized and is different from thinking mode and expressions of people at ordinary times. Thus, when ideological and political education is carried out, it is necessary to convert these highly converted languages into words and expressions that people are familiar with. When publicity is implemented, we should change profound language into straightaway words, avoid suing academic language when lectures are given and give full consideration to the audience's receptivity. Ideological and political educators act as translators, who make languages lacking fluency become straightforward ones and translate political language into common words, hoping people can accept them.

Since Marxism uses highly summarized language which is relatively abstract in essence, it is necessary for us to covert such an abstract language when we carry out publicity at ordinary times. Specifically, we should change 'cramming' methods in practical publicity and use equal communication mode to attract people to take part in ideological and political learning consciously. Content of publicity should be closely related to people's life and Marxism ought to permeate the content of publicity to make people accept education in a relatively relaxing environment.

\section{Make full use all kinds of media to permeate ideological and political education in people's life}

As knowledge economy comes, electronic information technology has been widely applied to all fields, which not only provides convenience for people's life but also offers lots of channels to cultural communication. Mobile phone, computer and network become a part of people's life, so it is a good way for ideological and political education of China to use these platforms to carry out ideological and political education undoubtedly, such as sending ideological and political content to people's mobile phones in the form of short messages and uploading content of ideological and political education to internet etc. Furthermore, we may use different cultural communication platforms to carry out and ideological and political education and publicity in many layers and aspects to make ideological and political education is related to people’s life closely. 


\section{Conclusion}

To sum up, Marxism provides footholds for ideological and political education of China in philosophy. From perspectives of both the theory of human nature and other aspects of Marxism, ideological and political education of China should start with Chinese people, enhance itself and make thoughts of Chinese people be able to cope with various challenges.

\section{Reference}

[1] Hu Kai and Wang Lingzhi. Marxist Humanology of Ideological and Political Education, Truth Seeking, 2009(2).

[2] Bai Xianliang. On Marxist Subject Attribute of Ideological and Political Education, School Party Construction and Ideological Education, 2010(11).

[3] Liu Jie and Liu Ji. Interpretation on Marxist Humanology in Ideological and Political Education at Colleges, Journal of Changchun University of Technology (Higher Education Study Edition), 2010(03).

[4] Zhu Qingshan. Marxist Hermeneutics in the Ideological and Political Education of Colleges and Universities: Inheritance and Transcendence, Journal of Zhejiang Wanli University, 2011(01).

[5] Guo Peiwen. Marxist Theory about Human Being and Its Guiding Significance for Ideological and Political Education of China, Journal of Social Science of Jiamusi University, 2012(01).

[6] Bai Xianliang. On Marxist Standpoint of Ideological and Political Education, Journal of Ideological \& Theoretical Education, 2012(11).

[7] Liu Huachu. Exploration Ideological and Political Education of Marxism in China at Present, Business, 2012(24). 